UDC 316:001.82:343.91-053.6

DOI: https://doi.org/10.21564/2663-5704.50.235187

Vodnik Valentyna Davidyvna, $\mathrm{PhD}$, Associate Professor, Associate Professor of the Department of Sociology and Political Sciences,

Yaroslav Mudryi National Law University, Kharkiv, Ukraine e-mail: tktyf1933@gmail.com

ORCID ID: 0000-0003-3652-4642

Klimova Galyna Pavlivna, Doctor of Philosophical Sciences, Professor, Professor of the Department of Sociology and Political Sciences, Yaroslav Mudryi National Law University, Kharkiv, Ukraine e-mail:klimova55@gmail.com ORCID ID: 0000-0002-6533-199X

Pidkurkova Iryna Valeriivna, $\mathrm{PhD}$ in Sociology, Associate Professor, Associate Professor of the Department of Sociology and Political Sciences, Yaroslav Mudryi National Law University, Kharkiv, Ukraine e-mail: podkurkovairina@gmail.com

ORCID ID: 0000-0003-4797-3718

\title{
SOCIOLOGICAL METHODS OF RESEARCH OF JUVENILE DELINQUENCY
}

This paper discusses some General issues of organizing and conducting an empirical study of juvenile delinquency. Special attention is paid to the methodology of research of the problem related to the personality and career of a minor criminal. In particular, the authors consider the peculiarities of using sociological methods to find out the personal qualities of juvenile offenders and the reasons that led to their committing offenses and crimes.

Keywords: research methodology, juvenile (minors), juvenile offenders, survey, observation, document analysis.

Problem setting. Crime has affected all spheres of life society. In this regard, an in-depth study of the nature, causes, consequences, and development trends of this social phenomenon is important, and has both scientific and practical significance. It should be the basis for improving social relations and civil society institutions, social norms and their application, for strengthening the system of social control, for more consistent implementation of measures of moral and legal education, social prevention and responsibility. All of them are aimed at ensuring maximum protec- 
tion of the individual, satisfaction of the interests of citizens, democratization and humanization of our society.

The internationalization of modern human life is accompanied by the internationalization of crime and the spread of its typical patterns, trends and forms to different regions and countries. Today, we are witnessing the rapid spread of crime among modern youth, which is a consequence of the problems that young people face on the way to becoming a person and finding their place in life. This makes it necessary not only to study the factors of deviant behavior of young people, which are common to all states, but also to critically assess the experience of countering antisocial phenomena in these countries. In recent years, views on the criminal behavior of young people and measures to combat it have changed significantly. However, scientists are united by the desire to describe and explain this phenomenon, as well as to justify the means of preventing it. Modern science has a whole arsenal of methods that have historically developed in the process of studying the phenomenon of crime among young people. One of the conditions for such research is the use of a set of sociological methods. Their peculiarity is the availability of resources for conducting and impartial evaluation of results. The study of modern world experience of effective counteraction to asocial and socially dangerous phenomena in the youth environment will help to identify new ways to solve problems related to overcoming and preventing youth deviation.

Recent research and publications analysis. Theoretical aspects of the problem of personality and behavior of juvenile delinquents are found in the works of M. C. Bassiouni \& Alan F. Sewell [1] and M. L. Benson [2]. Thus, M. C. Bassiouni \& Alan F. Sewell put forward the idea of the necessity to develop theories for the rehabilitation of juvenile delinquents, because those that exist usually do not correspond to the consensus between various scientific theories of human behavior [1]. Scientists based on the analysis and generalization of scientific theories of deviant behavior note the need to develop new contemporary theories and practices of rehabilitation of juvenile offenders. M. L. Benson provides an overview of research and theories of the approach to crime throughout life in his work [2]. This approach, based on the theory of the life cycle, describes the main concepts and problems in the field of criminology that a person faces throughout life. In particular, some sections of the work are devoted to the analysis of research on the role of the family in the problem of juvenile delinquency, as well as the relationship between youth crime and such stages of life as education, profession, and marriage.

Empirical data for the development of theoretical positions of this problem can be obtained using the methods of sociology. Works by such authors, such as I. V. Pidkurkova [3], Y. O. Roskopyna [4], O. H. Danylian, O. P. Dzoban 
[5, p. 539-542] is devoted to the sociological methods and their application in the study socio-legal spheres of society. So, I. V. Pidkurkova reveals the essence and considers the use of techniques of sociology in the study of various aspects of the court's activities, and provides examples of certain techniques in the practice of judicial studies [3]. Y. O. Roskopyna has revealed the value of sociological methods to prevent and pedagogical prevention of criminal offences in the youth environment [4].

The work of V. V. Holina \& B. M. Holovkin is devoted to the study of the personality of a minor criminal [6]. The authors of the article believe that the study of the identity of a minor offender will reveal the risk zones of their criminal career and prevent the appearance of misconduct among young people and recidivism among prisoners. The work was based on the analysis of research results using the analysis of archived criminal cases and interviews of convicts. The portrait of a minor criminal was formed based on the criteria of gender, age, education, social status, and nationality.

The social characteristics of juvenile delinquents and the reasons for their criminal behavior are discussed in the article V. D. Vodnik [7]. Considerable attention is paid to the factors that affect the Commission of crimes: a dysfunctional family, the shortcomings of the educational process, the problem of underage use of alcohol and drugs. Some areas of prevention of juvenile delinquency are indicated.

A wide range of scientific publications devoted to analysis of legal culture of juvenile offenders, the characteristics of sociological methods to assess the level of their legal awareness, formation of their motivation to stand with law-abiding behavior, to strengthen preventive work among adolescents, aimed at preventing unlawful behavior Thus, the article by G. P. Klimova provides a philosophical and legal justification of the essence of legal nihilism as one of the most common forms of deformation of legal consciousness [8]. The most characteristic features of modern legal nihilism are highlighted. The most important types of legal nihilism legal infantilism and legal negativism (radicalism) are analyzed. The nature of legal nihilism as a destructive social phenomenon is studied. The social danger of this social phenomenon is shown. N. I. Zhuchkova \& N. A. Bushina present the results of a study aimed at studying the perception of juvenile delinquency by adolescents, assessing the level of their legal awareness and legal culture [9]. Based on the data obtained, the authors propose measures to improve the policy in the field of preventing and combating juvenile delinquency.

O. V. Leshhenko on the example of Russia analyzes the current legal rules, which facilitate the formation of sense of justice for juvenile offenders and offers a contemporary understanding of the phenomenon of reflection of awareness of the juvenile offender as a condition that reflects its own consciousness of the individual understanding of the law and of the law [10]. 
We should also highlight the work of scientists who comprehensively study the problems of criminal career, especially from the point of view of the "life path" approach. One of the fundamental works on the career of a criminal is considered to be the book J. H. Laub \& R. J. Sampson [11]. Based on previous empirical studies, the authors examined a sample of men aged 14 to 70 years. One of the leading ideas of the work is that not all children who begin to live in an unfavorable social environment and show a tendency to misconduct can behave like this throughout their lives. The authors associate the variability of behavior with the social context. Criminal career is the subject of G. Zara research [12]. In his work, the author studies violent behavior of young people in order to reconstruct delinquent career and identify risk factors. The scientist makes his conclusions based on the results of the research using methods of analyzing official data and self-reports data.

Special attention was paid to the disclosure of the nature of criminal behavior of minors as a predictor of the trajectory of an adult's criminal career by D. M. Carkin \& P. E. Tracy [13]. They provide a large amount of data on the criminal history of crimes committed by minors, which allowed us to identify the factors that influence various variables on the trajectory of their criminal activity. At the same time, these authors mainly used the longitudinal study method when analyzing juvenile crimes. Because of this, the results obtained are not subject to broad generalization and transfer to other cohorts of juvenile offenders. In the study of the causes of criminal actions of teenagers, the work of Y. Antonan \& M. Goncharova is interesting [14]. Using methods of systematic analysis of empirical data and scientific modeling, the authors identify the most common factors that affect adolescent crime in modern conditions. The obtained results are proposed to be used for the development of new doctrinal approaches to the prevention of illegal behavior of children.

Among the factors that influence the occurrence of criminal behavior among minors, a special place is occupied by the family. Based on the results of the International Self-Report Delinquency Study 3 survey, B. Gualco, R. Rensi and G. Fossa investigate and identify the possible relationship between the family (family type, climate, role system, etc.) and the behavior of juvenile offenders [15].

V. D. Vodnik also explores the family, its potential as a factor influencing the formation and development of the personality of a minor criminal [16]. After all, the family forms an emotional and psychological mood, the level of self-esteem and self-criticism, directs the development of children in a certain direction, provides guidance on the performance of public and civil duties.

The problem of domestic violence against minors is covered by the work of A. B. Blaha, in which the author analyzes the possibilities of using the content 
analysis method in the study of this phenomenon and highlights the main results that were obtained with its help [17].

J. B. Sandera's work with a group of like-minded people is also devoted to the study of the influence of the family on the possibility of committing offenses and crimes by minors [18]. Background factors and possible risks are studied using qualitative methods. In particular, the authors suggest using Consensual Qualitative Research (CQR), that is, a team approach that takes into account checks and balances to solve the main problems and preserve the objectivity and integrity of the collected data from the stories and experiences of research participants. The sample of the trial study concerned teenagers and their families. The procedure involved semistructured interviews with minors and their mothers, the results of which were then analyzed by several researchers. The results obtained showed a significant influence on the behavior patterns of young offenders, the presence of discipline, social support of others and parents. This interesting method can be applied, but, like many qualitative methods, it has certain limitations. So, it can be used for search research, to identify the main areas of the problem, hypothesize, and model trends.

In recent years, more and more attention has been paid by law enforcement agencies and various social and psychological-pedagogical services to the creation of effective gender programs. This is due not only to the significant increase in delinquent and criminal behavior of underage girls indicated in many countries and the need to find ways to prevent and correct it, but also to a theoretically sound understanding and awareness of significant differences in the psychophysiological development of girls and boys, the causes and risk / protection factors that affect such behavior. A significant contribution to the understanding of these processes has been made by long-term joint research on the behavior of girls, conducted since 2000 by scientists from the UK and the US in Pittsburgh, Pennsylvania [19], as well as M. Zahn, S. Hawkins, J. Chiancone, A. Whitworth [20] and M. ChesneyLind, M. Morash, T. Stevens [21], members of the girls Study Group, created by the office of Juvenile Justice and Delinquency Prevention (OJJDP) in the United States. The study of gender characteristics of delinquent behavior, which is conducted in the United States, is in this regard a valuable experience for the development of gender prevention programs around the world.

Many works of Japanese scientists were devoted to the analysis of forms of prevention and control of manifestations of deviation in the adolescent environment. Their thoughts combine two approaches to determining the methodology for preventing deviation: criminological and sociological.

In particular, K. Schwarzenegger [22] and H. Fujita [23] pay attention to the legislative initiatives of the government of Japan, conducting research on the 
effectiveness of reforms in the field of education and juvenile justice. Strengthening the role of school education in curbing deviant behavior of adolescents, in their opinion, is one of the most important areas of youth policy.

M. Miney also explore the prospects for effective prevention of deviant behavior in school children and the possibility of further reform of the Japanese education system [24]. In particular, the scientist believes that the development of a structure that includes schools, families, and the local community is a major factor in reducing the level of adolescent deviation. A. Metzler, conducting research on Japanese correctional institutions for minors, note their high efficiency [25]. However, not enough attention is paid to the characteristics of various methods of studying the identity of juvenile offenders and the reasons for their criminal behavior.

Many mentioned scientists study the legal aspects of crime, but the phenomenon of crime is a social phenomenon. In addition, researchers usually study certain aspects of juvenile delinquency. Perhaps one of the reasons for methodological difficulties in the study of juvenile delinquency is the lack of application of a set of sociological methods for collecting and analyzing information about the criminal's identity, career, environment, and so on to explain the reasons for criminalizing human behavior and ways to prevent it.

Research aim is to analyze the possibilities of different sociological methods in the study of juvenile delinquency. Special attention is focused on the method of research of the problem related to the identity of a minor criminal, since without this it is impossible to successfully solve such issues as the nature of social causes of crime, the mechanism of their action, and ways to prevent the latter. The specificity of solving these problems dictates the use of the appropriate methodology, which development is dedicated to this work.

Methods. The use of certain sociological methods in any study is determined primarily by the subject, purpose, and objectives of the study of the problem. The research methodology was developed in such a way that the collected information contained information of both objective and subjective nature. The combination of these indicators (an objective-subjective complex) is one of the indispensable conditions for obtaining reliable results. We are talking about methods for obtaining the latter and processing the material. Processing is an independent step in this process, and the methods used in this process were considered at the first stages of the study. All methodological and methodological requirements for sociological research in general were taken into account when carrying out the study. The specificity was, first, in its content: in the initial theoretical premises, in the object and subject; and secondly, in its procedure, because when it comes to studying the crime, the perpetrators of the crime, the researcher always touches on the industry, clearly and in detail regulated by law. Therefore, the author's team constantly took care of accounting and compliance with the relevant legal requirements. 
It could also be pointed out that when studying, for example, the identity of the offender, the specifics of his position at the time of study, his psychological and mental state were considered. Stay in a special educational institution, educational and labor colony - an additional factor that requires consideration. On the one hand, teenagers in such institutions will experience the intense, purposeful influence of caregivers, on the other hand, being together with other offenders. Finally, the fact of group isolation, staying in isolation is of great importance.

In this work, based on the experience that has been studied in the scientific literature, some general questions of the methodology for organizing and implementing a specific study of juvenile delinquency are revealed. Special attention was focused on the methodology of research of the problem related to the identity of a minor criminal, since without this it is impossible to successfully solve such issues as the nature of social causes of crime, the mechanism of their action, and ways to prevent crime. The very features of solving these problems dictated the use of appropriate methods.

The participation of the authors in a comprehensive study of the problems of preventing juvenile crime in the big city become testing of scientific hypotheses about the possibilities of sociological methods in the study of juvenile crime in the big city, conducted by the research Academician Stashis Scientific Research Institute for the Study of Crime Problems of the National Academy of Legal Sciences of Ukraine. The study was based on data from a study that was conducted for 5 years in Kharkiv using traditional methods of obtaining information, such as analysis of documents, survey, observation.

The sample of survey units using these methods is:

(1) analysis of documents: a) materials of archival criminal cases (about 300), statistical data of the Department of information technologies of the Ministry of internal Affairs of Ukraine for 5 years; b) personal files of convicted minors (about 100) who are in the Kuryazhska colony.

(2) survey: a) minors who are enrolled in a special school (about 40), convicts of the Kuryazhska colony (350), students of secondary schools, colleges, lyceums, and vocational education centers (300). This made it possible to compare the responses of teenagers who committed a crime and those who made up the so-called control group; b) employees of law enforcement agencies, enterprises, public organizations, and juvenile services (50), teachers of secondary schools, colleges, lyceums, and vocational education centers (100).

If the favorable social conditions of development correctly shape the personality and the formation that broadly defines its behavior is stable, then the unfavorable ones are probably the same opportunities, but with respect to the negative influence. Numerous sociological and criminological studies of the living 
conditions and upbringing of such persons have shown that these conditions are usually very different from those in which minors from the control group lived and developed.

\section{Paper main body. Analysis of documents in the study of juvenile delinquency.} Document analysis was one of the methods for collecting information about juvenile delinquency. Documents were used as materials for law enforcement activities. But there are some things that made it difficult to use this group of documents as a source of information. For example, when analyzing crime, criminal statistics data did not always meet the task. Some important for us facts are not recorded in the reports, the grouping of the material did not coincide with the principles of classification. In such situations, the source of primary information was only the criminal cases themselves. The results of the analysis of criminal cases of juvenile offenders show that the crime was committed under the influence of alcohol in $23.1 \%$, strong alcohol intoxication in $2.1 \%$, and drug intoxication in $0.4 \%$ of cases. $4.3 \%$ of minors were registered in a psycho-neurological dispensary, $1.7 \%$ were previously there.

Generalization of judicial practice was an important source of information, where attention was focused on the court's activities as a social institution, and not on the problems of legislation or quality standards (law enforcement of facts). Familiarization with the practice of reviewing cases of certain categories allowed us to achieve the goals of crime research, the causes and conditions that contribute to the Commission of crimes, and the analysis of individual contingents of criminals.

According to the results of the study of archived criminal cases against minors who committed crimes, $36.8 \%$ grew up and were raised in single-parent families, and among minors in the control group $-26.4 \%$ (Graf. 1).

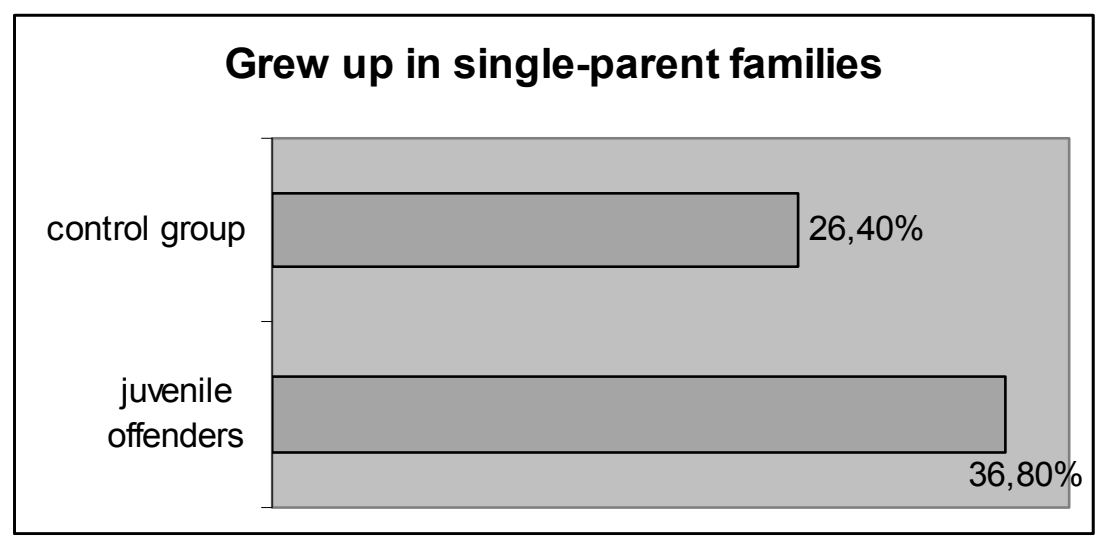

Graf. 1 
It should be noted that the incompleteness of the family is an important demographic characteristic that has a criminological significance. A constant companion of juvenile crimes, one of the conditions that contributes to their Commission is neglect. This is clearly evidenced by the materials of investigative and judicial practice, scientific research. The close link between neglect and crime is understandable. According to the study, $25.4 \%$ of minors committed a crime from 20 to 24 hours, $11.9 \%$ from 0 to 4 hours. As one of the conditions for committing a crime, weak control over minors affects- $61.6 \%$ (according to the analysis of court cases of juvenile offenders). This is not just about weakening the formal control of parents over the behavior of children, but also about the existing microclimate of the family, serious defects in the attitude of parents to their functions as a caregiver, demonstrating to children social irresponsibility, indifference to their fate, or the obvious impossibility for children to fully perform these functions.

When studying the personality of a juvenile offender, a comparative analysis of the personal characteristics of offenders and law-abiding adolescents was used, which covered: a) socio-demographic and educational and cultural indicators; b) the needs and interests of minors; c) their emotional and volitional sphere; d) ethical and legal views and beliefs; e) the motives of their behavior.

In the process of studying this problem, statistical documents that contained information and judgments in a quantitative (numerical) form were used, systematized and summarized in a table, graphs, diagrams, and the like. Statistical observations were carried out constantly and recorded in detail public life from many sides for a long time. This made it possible to analyze, compare and predict the development of objects, and conduct quantitative and qualitative analyses. Statistical accounting is characterized by a high level of scientific validity, efficiency and specificity. Therefore, legal statistics provide reliable factual material. Many facts were obtained from other statistical fields (economic, demographic, and medical).

Analyzing the data of statistical cards for convicted adolescents, for example, a certain relationship between their age and the structure of crimes committed by them (the number of crimes committed while intoxicated increases with age); differences in crime depending on gender, educational level (compared with the control group, the low educational level of juvenile offenders was distinguished). There is a certain connection between the nature of the crime and their occupation.

Information about the state of mind of adolescents was obtained both from acts of forensic psychiatric examinations, and from materials of children's clinics, psychoneurological dispensaries, and other methodological documents. The organization of a special study has caused difficulties, since such a survey requires the consent of the child and his parents (guardians). 
Information about the motivational sphere, moral and legal views of juvenile offenders was obtained through the use of research methods such as observation, individual interviews with offenders, their parents, employees of the criminal police for minors, staff of special educational institutions for children and adolescents, labor colonies, as well as questionnaires, the study of personal files of prisoners and other documents.

From the writings of life stories of teenagers from educational institutions, in which they wrote about members of their family, family relationships, the established social portrait of the environment in which minors grew up. From these texts, information was obtained about their personal traits, features, including their own assessment of life priorities and benefits. These data help in pedagogical work with children who are in special educational institutions, general education schools, vocational training centers, social rehabilitation, and so on.

Information about juvenile offenders was provided by their autobiographies, which covered social situations in their order and relationship, painted a picture of the mental appearance of their authors, and finally showed them in the context of the social environment in which they lived and acted. Such materials for analysis could not give any letters or other documents that show only a certain period of the author's life. Such documents were useful in studying the legal awareness of the offender, the role of the microenvironment in the formation of anti-social orientation of the individual.

Obtaining valuable autobiographical material from minors while they were serving their sentences with imprisonment created great difficulties caused by the mental resistance of the subjects before presenting their intimate experiences in prison isolation. The convict must feel that the information about himself that he transmits to the researcher is not a satisfaction of the latter's curiosity. They can not be used as burdening material on the author, but are collected in order to determine the proper direction of his fate for the period of his stay in correctional labor institutions, and if necessary, to help him after his release.

In such surveys, the minor received a diagram that describes the moments of his behavior and development that we were interested in. Under certain conditions, this method of provoked autobiographies yields extremely valuable results. The resulting autobiographical material differs from all other information about the convicted person in that it is written by them using their own words, turns of their language, and is not a paraphrase of the statements "questions and answers".

Using the autobiographical method, we studied such aspects of personality that were not directly observed and studied. These are: tracking the influences that contribute to the identification of certain individual characteristics of the individual person; the influence of moments of heredity, predisposition, family influence, 
environment, living conditions, and so on. When investigating juvenile delinquency, personal documents such as letters and diaries were also taken as a source of information. For example, maiden handwritten love stories, diaries were an important and fairly reliable source of information about the structure of virgin deviant behavior. Speaking about the method of document analysis used by us, it should be noted that criminologists often use it in their research. But from a sociological point of view, not only the dry facts of statistics, objective data of criminal cases, acts of forensic psychiatric examinations, and so on are interesting, but also the life stories of juvenile offenders themselves, which are studied using the autobiographical method. Given all the possibilities of the document analysis method, it should be noted that it is unlikely for a complete comprehensive study of the identity of juvenile offenders, it is exhaustive.

Survey method in the study of juvenile delinquency. The proposed method should use one of the most common sociological methods of collecting information a survey, and in the form of an interview (which allows you not only to record the answers to questions, but also to monitor the response of the Respondent). When studying, for example, the identity of the offender considered the specifics of his situation at the time, his psychological and mental state. Being in a special educational institution was an additional factor that needed to be considered. On the one hand, teenagers in such institutions experienced intensive targeted influence of educators, on the other were together with other offenders. Finally had a meaning and the fact of being in isolation. When interviewing a teenager in educational colonies and special educational institutions, it was necessary to keep in mind that any meeting with new people he considers from the point of view of speeding up his release, and therefore often wanted to show himself in a more favorable view. This required the use of additional methodological techniques. In any case, in the course of the study and in the processing of its results, the distinction was made between those who were interviewed at large and those who were interviewed in closed institutions.

In studying the identity of a juvenile offender used a comparative analysis of the characteristics of offenders and law-abiding juveniles obtained during the survey. The questionnaire covered the following blocks of questions: sociodemographic characteristics, needs and interests of teenagers, motives for their behavior, ethical and legal views and beliefs, living conditions and education, state of social control. The study covered the entire period of development of adolescents, the formation of their personality. For juvenile offenders, the questionnaire questions concerned their past, especially the time before the crime.

Information about offenders was also collected through interviews with law enforcement officials, institutions, businesses, public organizations, and other 
citizens. These interviews had the advantage that they allowed you to put new questions behind those items and sections of the program that were not sufficiently clarified, therefore, allowed you to significantly Supplement the existing information. According to scientists, teachers, employees of various institutions that deal with minors, the main cause of juvenile delinquency is the unfavorable situation in the family and its negative impact.

Family trouble is a complex concept that has a number of features, in particular: a) violation of the family structure (incomplete families); b) the inferiority of the moral position of its members; c) the shortcomings and distortion of the pedagogical knowledge of parents, their lack of child-rearing skills.

Recently, sociologists, psychologists, and lawyers have begun to include a violation of the emotional and psychological community of the family among the signs of family distress. For families of students from the control group, it is not very typical to read and discuss books, Newspapers, fiction, listen to music together (more than $52 \%$ of responses), or have a rest together (visit cinemas, theaters, walks) (about $43 \%$ of responses). Often this plays an "auxiliary" role, because it is associated with the flawed moral position of parents, which can directly generate illegal behavior of children. At the same time, the violation of emotional and psychological community, as it seems, can play an independent role of a criminogenically significant factor. The absence of this community causes the family to lose the properties of the collective. It often leads to a decrease in the educational influence of the family on the teenager. Social psychologists note that the atmosphere of emotional attachment, closeness, trust and love determines the intensity, strength, and depth of the child's assimilation (in the process of imitation and empathy) of the parents' moral positions and their value orientations in the sphere of morality. In an atmosphere of mutual understanding, the child better perceives the conscious instructions and demands of parents. Violation of emotional and psychological community, family conflict can affect the mental health of children.

The lack of proper demands on the minor, his actions, and even indifference, providing independence in assessing, solving certain life situations - one of the embodiments of neglect. So, according to the surveyed students from the control group, they can solve the question about smoking ( $20.1 \%$ of the answers), friendship with previously convicted persons (more than $19 \%$ of the answers), and sexual life (more than $47 \%$ of the answers) themselves. It is necessary to prevent and stop the process of turning children into street children, who make up a large layer of minors involved in criminal activities.

The problem of juvenile delinquency is not limited to dysfunctional families, although for teenagers who grew up in them, the criminal risk increases by 
4-5 times compared to peers from families where there are no obvious examples of daily anti-social behavior. Many dysfunctional families have several types of anti-social behavior. In the control group, $7.5 \%$ of respondents are very typical for family members, alcohol abuse, drugs; for $6.7 \%$ - quarrels, conflicts, fights; for $6.8 \%$ - unfriendly attitude to other people.

There are three forms of criminal influence that these anti-social manifestations have on the spiritual world and behavior of a juvenile on the part of adult family members. The first is the active involvement of minors in drunkenness, drug use and other intoxicating substances, fights, debauchery, and committing offenses. Not all teenagers who use drugs and alcohol are registered in time. The vast majority of adolescents who are identified and registered are persons who have committed socially dangerous acts or crimes, but minors who use drugs and alcohol but have not yet committed any illegal acts are rarely detected. But it is necessary to take into account that it is from their side that the commission of crimes and other antisocial actions should be expected in the future.

The second form of criminal influence is a "passive" example of unpunished anti-social behavior, perceived by children as a stereotype of habitual, everyday, normal behavior. Many hooligan actions of minors are simply related to the fact that they reproduce in a public place the stereotypes of behavior that they are used to in the family as the norm. The third is pushing children out into the street, their frustration with their parents, a sense of their own inferiority, and tension. And these feelings often become the basis for forming a negative attitude to others, disbelief and hostility to the norms and principles of moral behavior, as well as for getting into informal companies with a negative orientation, searching for a strong, brave, friendly, attentive older friend who can become an ideal for a teenager. The materials of the survey of special school students, the study of criminal cases of juvenile offenders indicate that $20.9 \%$ had normal, and $18.8 \%$ had abnormal relations in the family, $2.6 \%$ did not maintain relations with the family. About $61 \%$ of students in the control group identified their relationship with their parents as good (based on mutual assistance, mutual understanding, trust), about $19 \%$ as normal. At the same time, more than $7 \%$ of respondents noted that their relationship with their parents is not very good, more than $8 \%$ indicated that there are differences. More than $5 \%$ of respondents have different attitudes.

A dysfunctional family forms children in its own image. In many cases, young people who have adopted a cynical attitude to moral values, disrespect for the people around them, and a disdain for social norms of behavior leave the family - unless the conditions of life and upbringing are normalized in time as a result of external interference. More than $27 \%$ of the surveyed students of the Kuryazhska colony believe that it is very important to be strong and cruel in order to achieve success in life, more than $70 \%$ - resourceful and dexterous. In the control group, multivariate 
responses were given, in particular: about $95 \%$ of students, it is important to be purposeful in order to achieve success in life, about $85 \%$ - to have a higher education, about $70 \%$ to be honest and truthful (Graf. 2, Graf. 3).

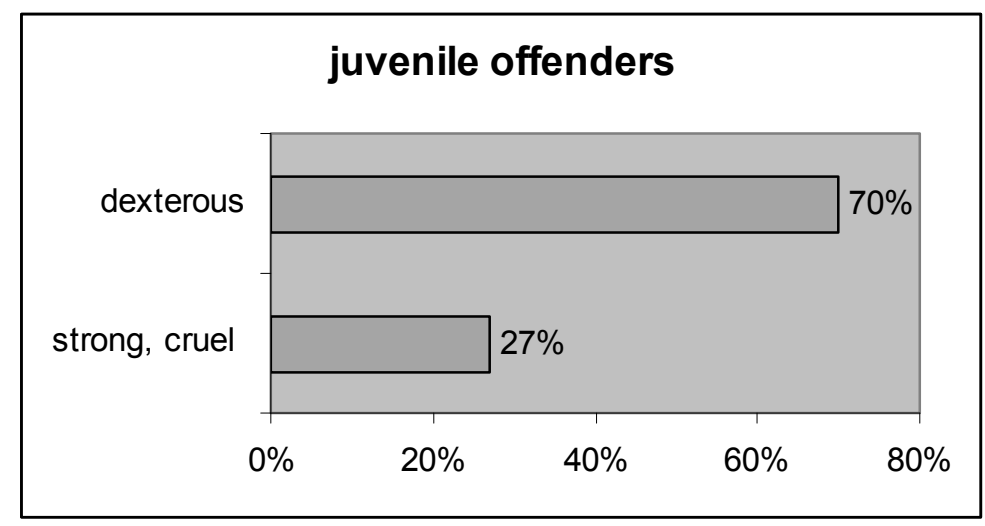

Graf 2. Top ranked qualities for success

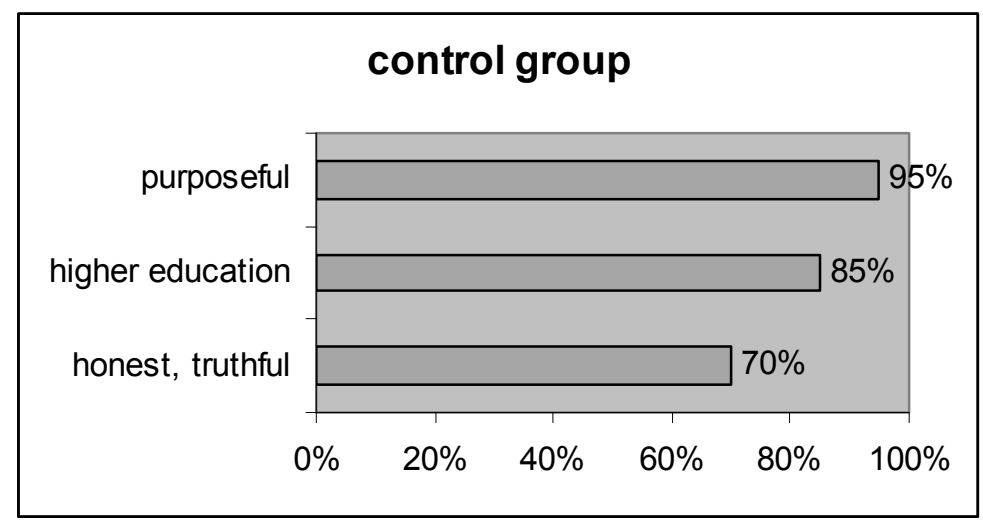

Graf. 3. Top ranked qualities for success

Therefore, negative behaviors of adult family members contribute to the fact that the minor does not just adopt negative behaviors, but acquires a negative value orientation, implementing it in their own anti-social behavior. This, in particular, affects the motives and nature of the crimes. A state program is needed to overcome all types of family problems to neutralize the unfavorable situation in the family and its negative impact on the criminalization of minors. The decline of the moral position of family members, the wrong pedagogical position of parents are considered as components of family trouble. According to the assessment of 
teachers and employees of juvenile services, this position is characterized by an unwillingness to engage in the upbringing of children in principle (about $18 \%$ of the materials of the study of criminal cases of juvenile offenders noted an indifferent attitude on the part of parents); in the control group these indicators are much less. Parents of minors from the control group are interested in their studies, behavior, experiences, friends, and leisure activities almost every day (more than $71 \%$ of responses); underestimating the need to engage in education constantly, consistently complicating its goals (such circumstances in the families of offenders were more common than in the families of minors in the control group); using a limited set of educational tools, mainly conversations or physical punishments (more than $29 \%$ of offenders Kuryazhska colony believed that their parents reacted gently to their childish pranks and faults, acting with teachings, but almost half (46.8\%) reported that they were deservedly beaten for their faults; $5.7 \%$ said that they were subjected to severe beatings and torture. Students from the control group noted that they were interviewed at home for misconduct (more than $37 \%$ of responses), shouted at, and scolded (about $30 \%$ of responses). $24 \%$ pointed to various methods of punishment (do not give "pocket" money, do not buy new things, do not let out on the street, forbid to play computer, watch TV, condemn, treat indifferently, ignore, do not talk, etc.); increased guardianship (the study showed that parents of juvenile offenders tend to be insufficiently critical of miscalculations in the upbringing of their children. Only a few are actually aware that these miscalculations are taking place, while most parents tend to explain the difficulties of their children by the immoral influence of their friends, the shortcomings of educational work at school, and the like). It was interesting to observe teenagers, for example, for spending their free time, for behavior in public places.

Generalization of results. The use of these methods of collecting primary information required a specially developed set of methodological documents a dossier that included the following programs: a) observation of the criminal case; b) a formalized interview with a minor criminal, his parents, educators (teachers), friends; c) the study of the personal file of the prisoner; d) a questionnaire that revealed the criminogenic "infection" of the microenvironment of the examined teenager (data on crimes committed with impunity, on persons who were brought to criminal responsibility from among relatives, neighbors, friends and other acquaintances); the plan of the autobiography. In addition, the dossier contained final data on the results of studying the identity of a minor offender. This information was summarized in a special "Card of the complex study of the personality of a minor offender and the social situation of its development", which was a final document. All the data obtained were statistically processed using different groupings. 
"Card of the comprehensive study of the personality of a minor offender and the social situation of its development" was developed by N. V. Belyaeva, A. I. Dolgova, N. A. Dremova, V. D. Ermakov. We offer a simplified schematic sample of this document (Table).

Table

Sample "Cards of the comprehensive study of the personality of a minor offender and the social situation of its development"

\begin{tabular}{|l|l|l|}
\hline & \multicolumn{1}{|c|}{ Indicators } & Content \\
\hline 1 & the crime and the situation of its commission & \\
\hline 2 & $\begin{array}{l}\text { the identity of the offender } \\
\text { a) socio-demographic portrait (gender, age, nationality, } \\
\text { etc.) } \\
\text { b) ethical and legal characteristics } \\
\text { c) life plans and aspirations }\end{array}$ & \\
\hline 3 & $\begin{array}{l}\text { real social behavior } \\
\text { a) prior to committing a crime } \\
\text { b) in a remand prison } \\
\text { c) in special educational institutions }\end{array}$ & \\
\hline 4 & $\begin{array}{l}\text { microconditions of formation and life of the teenager } \\
\text { (family and immediate surroundings) } \\
\text { a) parents } \\
\text { b) other relatives } \\
\text { c) neighbors } \\
\text { d) friends } \\
\text { e) school } \\
\text { e) mass media } \\
\text { etc. }\end{array}$ & \\
\hline
\end{tabular}

In general, full information for the necessary analysis is provided by the study of criminal cases and conversations with convicts. It is important that the study covered the entire period of development of the minor, the formation of his personality, especially the time that preceded the last crime, as well as when the teenager was in a pre-trial detention center and a colony. The main attention was paid to the collection, recording and analysis of data in the Card: a) about microconditions of formation and life of the teenager; $b$ ) characterizing minors by real social behavior (prior to committing a crime, in a remand prison and in special educational institutions); c) about the crime and the situation of its commission that is directly related to the personal characteristics of the perpetrator. 
All this information was recorded in their genesis, covering the process of interaction of the individual, the situation and the microenvironment. In addition, the proposed method allows you to fully identify and record the features that make up the socio-demographic portrait of a juvenile offender, his parents or persons who replace them.

Filling out the Card and summing up all the obtained objective indicators, an assessment of the minor offender is given, considering: a) his behavior as a system of actions; b) the connection of the last crime with the previous behavior; c) the degree of deformation of his microenvironment. It is clear that many questions of identical content are included in questionnaires, formalized interviews, and other methodological documents. This makes it possible to compare the results obtained and allows you to easily summarize them when filling out the main final document and provide the obtained data with a quantitative reflection. Thus, the final result of the study should not be considered as generalized results of surveys, analysis of documents, etc., which are often presented as tables with brief comments, but a scientific report that outlines theoretical conclusions about the confirmation or refutation of hypotheses about the state of the scientific problem after its empirical study, the scientific validity of the methods used and recommendations for their improvement and further application.

Conclusions of the research. The analysis of the data allowed us to identify the most characteristic personality traits of juvenile offenders, as well as the reasons and conditions for their criminal behavior. We assumed that the formation of personality is determined not only by the micro-environment, but also by the macroenvironment. In other words, minors will always experience the influence not only of their immediate environment: parents, caregivers, friends, neighbors, etc., but also the influence of the entire society and the state, which is carried out through the appropriate educational institutions, the media, public organizations, and so on. And in this aspect, juvenile delinquency is a consequence not only of family problems, the negative influence of the immediate environment, but also of certain features of the socio-economic and legal political development of society in the modern period [26, p. 410-411].

The development of this problem may have not only theoretical but also practical interest. The question about how specific studies in juvenile crime is one of the most important, because the scientific validity of appropriate methodology, their adequacy to the purposes, object and subject of study, the ability of the researcher to use them, depend on the reliability and validity of generated data, which certainly will contribute to the development of a program of personal development in the state (in general and social policy of the state), professional (efforts of experts) and 
individual levels (with the efforts of the children themselves), as well as prevention of this phenomenon.

The methodology used in the pilot study, based on sociological methods, allowed a comprehensive analysis of the phenomenon of juvenile delinquency in statics and dynamics and to make a "Card of a comprehensive study of the personality of a juvenile offender and the social situation of its development.» The result of the work opens up the prospect of identifying new signs of juvenile delinquency, which can give rise to new directions of scientific research.

\section{REFERENCES}

1. Bassiouni, M. C., \& Sewell, A. F. (1974). Scientific Approaches to Juvenile Delinquency and Criminality. DePaul Law Review, 23(4), 1344-1407. https://via.library.depaul.edu/ law-review/vol23/iss4/3.

2. Benson, M. L. (2013). Crime and the life course: an introduction (2nd ed.). New York, NY: Routledge.

3. Pidkurkova, I. V. (2017). Vykorystannia sotsiolohichnykh metodiv u doslidzhenni roboty sudu [The use of sociological methods in the study of the court]. Problemy zakonnosti - Problems of Legality, 139, 247-253 [in Ukrainian]. DOI: https:// doi.org/10.21564/2414-990x.139.115215.

4. Roskopyna, Yu. O. (2011). Znachennia sotsiolohichnykh metodiv mizhnarodnoi kryminolohii dlia pedahohichnoi profilaktyky kryminalnykh zlochyniv u molodizhnomu seredovyshchi [The Importance of Sociological Methods of International Criminology for Pedagogical Prevention of Criminal Offenses in the Youth Environment]. Visnyk Cherkaskoho universytetu. Seriia "Pedahohichni nauky" - Bulletin of the Cherkasy Bohdan Khmelnytsky National University. Series "Pedagogical Sciences", 203, Part II, 75-81 [in Ukrainian].

5. Trebin, M. P. (Ed.). (2020). Sotsiolohiia prava: entsyklopedychnyi slovnyk [Sociology of Law: Encyclopedic Dictionary]. Kharkiv: Pravo [in Ukrainian].

6. Holina, V. V., \& Holovkin, B. M. (2006). Osobystist nepovnolitnoho zlochyntsia: kryminolohichnyi portret (na materialakh $\mathrm{m}$. Kharkova) [The Identity of the Juvenile Offender: A Contemporary Criminological Portrait (On Materials of the City of Kharkiv)]. Biuleten Ministerstva yustytsii Ukrainy - Bulletin of the Ministry of Justice of Ukraine, (1), 42-53 [in Ukrainian].

7. Vodnik, V. D. (2015). Zlochynnist nepovnolitnikh: prychyny ta shliakhy zapobihannia (za danymy doslidzhennia u m.Kharkovi) [The Criminal Nature of Juvenile: Causes and Means of Prevent (From Data of Research in Kharkiv)]. Visnyk Natsional'noho universytetu "Yurydychna akademiya Ukrayiny imeni Yaroslava Mudroho". Seriia: Filosofia, filosofiia prava, politolohiia, sotsiolohiia - The Bulletin of Yaroslav Mudryi National Law University. Series: Philosophy, Philosophies of Law, Political Science, Sociology, 26(3), 155-178 [in Ukrainian]. 
8. Klimova, G. P. (2013). Pravovoi nihilizm yak forma deformatsii pravosvidomost [Legal Nihilism as a Form of Justice Deformation]. Visnyk Natsional'noho universytetu "Yurydychna akademiya Ukrayiny imeni Yaroslava Mudroho". Seriia: Filosofiia, filosofiia prava, politolohiia, sotsiolohiia - The Bulletin of Yaroslav Mudryi National Law University. Series: Philosophy, Philosophies of Law, Political Science, Sociology, 19(5), 105-112 [in Ukrainian].

9. Zhuchkova, N. I., \& Bushina, N. A. (2019). Pravonarushenija i prestuplenija nesovershennoletnih: politika gosudarstva i vosprijatie javlenija podrostkami [Offenses and Crimes of Minors: The State Policy and Perception of the Phenomena by Teens]. Social'no-politicheskie issledovanija - Social and Political Researches, (2), 72-80 [in Russian].

10. Leshhenko, O. V. (2016). K voprosu o ponimanii refleksii pravosoznanija nesovershennoletnih osuzhdennyh [Revisiting the Understanding of Legal Consciousness Review of Convicted Minors]. Interaktivnaja nauka - Interactive Science, 5, 92-94 [in Russian].

11. Laub, J. H., \& Sampson, R. J. (2003). Shared beginnings, divergent lives: delinquent boys to age 70. Cambridge, Mass.: Harvard University Press.

12. Zara, G. (2019). La realtà criminogenica nello sviluppo di una carriera delinquenziale e violenta giovanile. Uno studio esplorativo. Rassegna Italiana Di Criminologia, (1), 49-64.

13. Carkin, D. M., \& Tracy, P. E. (2017). Prediction of Adult Criminal Careers from Early Delinquency Offense Characteristics in the 1958 Philadelphia Birth Cohort. The Criminology, Criminal Justice, Law \& Society, 18(1), 71-87.

14. Antonan, Y., \& Goncharova, M. (2018). Sostojanie i prichiny prestupnosti nesovershennoletnih v Rossii [Present state and causes of juvenile delinquency in Russia]. Vestnik Moskovskogo gosudarstvennogo oblastnogo universiteta. Serija: Jurisprudencija - Bulletin of Moscow Region State University. Series: Jurisprudence, (2), 87-100. DOI: https://doi.org/10.18384/2310-6794-2018-2-87-100 [in Russian].

15. Gualco, B., Rensi, R., \& Fossa, G. (2015). Famiglia, presenza dei genitori e comportamenti devianti dei giovani in Italia: dati di una ricerca multicentrica effettuata tramite questionari self-report. Rassegna Italiana Di Criminologia, 9(3), 177-194 [in Italian].

16. Vodnik, V. D. (2019). Dysfunctional Family as One of the Factors of Juvenile Deliquency. Visnyk Natsional'noho universytetu "Yurydychna akademiya Ukrayiny imeni Yaroslava Mudroho". Seriia: Filosofiia, filosofiia prava, politolohiia, sotsiolohiia - The Bulletin of Yaroslav Mudryi National Law University. Series: Philosophy, Philosophies of Law, Political Science, Sociology, 43(4), 133-142. DOI: https://doi.org/10.21564/2075-7190.43.187933.

17. Blaha, A. B. (2005). Mozhlyvosti metodu kontent-analizu presy pry doslidzhenni problemy nasylstva v simi stosovno nepovnolitnikh [Possibilities of the Press Content 
Analysis Method in the Research Problems of Violence in the Family of Minors]. Visnyk Kharkivskoho Natsionalnoho universytetutu vnutrishnikh sprav - Bulletin of Kharkiv National University of Internal Affairs, 30, 78-83 [in Ukrainian].

18. Sandera, J. B., Sharkeyb, J. D., Olivarria, R., Tanigawab, D. A., \& Mausetha, T. (2010). A Qualitative Study of Juvenile Offenders, Student Engagement, and Interpersonal Relationships: Implications for Research Directions and Preventionist. Approaches Journal of Educational and Psychological Consultation, 20(4), 288-315. DOI: https:// doi.org/10.1080/10474412.2010.522878.

19. Farrington, D. P. (2006). Building developmental and life-course theories of offending. In F. T. Cullen, J. P. Wright, K. R. Blevins (Eds.), Taking Stock: The Status of Criminological Theory (pp. 335-364). New Brunswick, N. J.: Transaction Publisher.

20. Zahn, M., Hawkins, S., Chiancone, J., \& Whitworth, A. (2008). The Girls Study Group - Charting the way to delinquency prevention for girls. Washington, DC: Office of Juvenile Justice and Delinquency Prevention. https://ojjdp.ojp.gov/library/ publications/girls-study-group-charting-way-delinquency-prevention-girls.

21. Chesney-Lind, M., Morash, M., Stevens, T. (2008). Girls' Troubles, Girls' Delinquency, a Gender-Responsive Programming: A review. Australian \& New Zealand Journal of Criminology, 41(1), 162-189. DOI: https://doi.org/10.1375/acri.41.1.162.

22. Schwarzenegger, c. (2003). The Debate About the Reform of the Juvenile Law in Japan. In G. Foljanty-Jost (Ed.), Juvenile Delinquency in Japan: Reconsidering the "Crisis" (pp. 173-198). Leiden; Boston, MA: Brill.

23. Fujita, H. (2003). The Reform of the Japanese Education System as an Answer to Delinquency. In G. Foljanty-Jost (Ed.), Juvenile Delinquency in Japan: Reconsidering the "Crisis" (pp. 143-172). Leiden; Boston, MA: Brill.

24. Minei, M. (2003). The Revival of Social Networks for Prevention of Juvenile Delinquency. In G. Foljanty-Jost (Ed.), Juvenile Delinquency in Japan: Reconsidering the "Crisis" (pp. 211-220). Leiden; Boston, MA: Brill.

25. Metzler, A. (2003). The Juvenile Training Schools of Japan - Teaching Young Serious Offenders How to Live and "How to Be". In G. Foljanty-Jost (Ed.), Juvenile Delinquency in Japan: Reconsidering the "Crisis" (pp. 221-252). Leiden; Boston, MA: Brill.

26. Vasyliev, H. Yu., Vodnik, V. D., Volianska, O. V., et al. (2013). Hromadianske suspilstvo: politychni ta sotsialno-pravovi problemy rozvytku [Civil Society: Political and Socio-Legal Problems of Development]. Trebin, M. P. (Ed.). Kharkiv: Pravo [in Ukrainian]. 
Воднік Валентина Давидівна, кандидат філософських наук, доцент, доцент кафедри соціології та політології, Національний юридичний університет імені Ярослава Мудрого, м. Харків, Україна

Клімова Галина Павлівна, доктор філософських наук, професор, професор кафедри соціології та політології, Національний юридичний університет імені Ярослава Мудрого, м. Харків, Україна

Підкуркова Ірина Валеріївна, кандидат соціологічних наук, доцент, доцент кафедри соціології та політології, Національний юридичний університет імені Ярослава Мудрого, м. Харків, Україна

\section{СОЦІЛОГІЧНІ МЕТОДИ ДОСЛІДЖЕННЯ ЗЛОЧИННОСТІ НЕПОВНОЛІТНІХ}

Постановка проблеми. Питання злочинної поведінки неповнолітніх залишається сьогодні одним з найактуальніших і тому потребує глибокого вивчення, зокрема i на емпіричному рівні за допомогою сочіологічних методів. Від наукової обтрунтованості відповідних методів, їх адекватності иілям, об'єкту та предмету дослідження, від уміння дослідника користуватися ними залежать надійність і вірогідність одержуваних даних, щзо, безумовно, сприятиме розробленню програми розвитку особистості на державному (у загальній і соџіальній політиці держави), фаховому (зусиллями спеціалістів) та індивідуальному (зусиллями самих неповнолітніх) рівнях, а також профілактищі иього явища.

Аналіз останніх досліджень і публікацій. Загальнотеоретичні аспекти порушеної проблеми відомі з прачь Ю. М. Антоняна, А. Б. Благи, Т. З. Гарасимів, В. В. Голіни, М. В. Гончарова, І. М. Даньшина, Г. П. Клімової та ін. Характеристиці соиіологічних методів та їх застосуванню в дослідженні сочіально-правової сфери суспільства присвячено роботи таких авторів, як I. В. Підкуркова, Ю. О. Роскопіна та ін. Природу злочинної поведінки неповнолітніх, фактори ї̈ формування, застосування соиіологічних методів під час вивчення ивого явища досліджували Д. М. Каркін, П. Е. Трейсі, В. Д. Воднік. Аналізу форм профілактики й боротьби з проявами девіаиії в підлітковому середовищі присвятили багато пращь Х. Фудзита, Й. Накано, М. Міней, К. Швариенеггер, А. Метилер.

Формулювання цілей. Стаття має на меті аналіз можливостей соціологічних методів у вивченні злочинності неповнолітніх, а також формування методики комплексного дослідження особистості неповнолітнього злочиния.

Виклад основного матеріалу. Проблема вивчення особистості неповнолітнього правопорушника - комплексна. Вона потребує ретельного і всебічного підходу. Збирання первинної інформації про особу неповнолітнього злочиния стає ефективним із використанням групи соціологічних методів, кожен з яких виконує своє гносеологічне призначення. Запропонована у статті методика була апробована на конкретному сочіологічному дослідженні проблеми злочинності серед неповно- 
літніх. Одним із методів збору інформації про злочинність неповнолітніх є аналіз документів. Документами слугували матеріали правозастосовної діяльності. Важливим джерелом інформачії є також узагальнення судової практики. Ознайомлення з практикою розгляду справ певних категорій дозволило досягти иілей дослідження злочинності, причин та умов, які сприяють учиненню злочинів, аналізу окремих контингентів злочинців. У прочесі дослідження використовувалися статистичні документи, які містили відомості й судження в кількісній (чисельній) формі, систематизовані і зведені в таблиці, графіки, схеми тощо. Статистичні спостереження здійснювалися постійно й детально фіксували суспільне життя з багатьох боків протягом тривалого часу. Це дало змогу аналізувати, порівнювати і прогнозувати розвиток об'єктів, провадити кількісний і якісний аналізи. Про стан психіки підлітків інформацію було отримано як з актів судово-психіатричних експертиз, так $і$ з матеріалів дитячих поліклінік, психоневрологічних диспансерів, інших методичних документів. Інформачію про мотивачійну сферу, моральні та правові уявлення неповнолітніх злочинців було одержано шляхом застосування таких методів дослідження, як спостереження, індивідуальні бесіди з правопорушниками, їх батьками, працівниками кримінальної поліџї̈ у справах неповнолітніх, персоналом спеціальних навчально-виховних установ для дітей і підлітків, трудових колоній, а також анкетування, вивчення особистих справ ув 'язнених та інших документів. Інформацію про неповнолітніх правопорушників надали їх автобіографії, які висвітлювали сочіальні ситуаиії в їх черговості і зв'язку, малювали картину психічного образу їх авторів, нарешті, показували їх у тому контексті сочіального середовища, у якому вони жили і діяли. Відомості про правопорушників збиралися також шляхом опитувань працівників правоохоронних органів, установ, підприємств, громадських організачій та інших громадян. Використання перелічених методів збирання первинної інформації потребувало спеціально розробленого комплексу методичних документів - досьє, яке включало такі програми: а) вивчення кримінальної справи; б) формалізованого інтерв'ю з неповнолітнім злочинием, його батьками, вихователями (педагогами), друзями; в) вивчення особистої справи ув 'язненого; г) анкету, що дозволила виявити криміногенну «зараженість» мікросередовища обстежуваного. Крім того, досье містило підсумкові дані за результатами вивчення особистості неповнолітнього правопорушника. Ці відомості узагальнювалися в спечіальній «Карті комплексного вивчення особистості неповнолітнього злочиния і соціальної ситуації ї̈ розвитку», яка становила собою підсумковий документ. Усі отримані дані зазнали статистичної обробки із застосуванням різних угруповань.

Висновки. Розроблення цієё проблеми може мати не тільки теоретичний, а $i$ практичний інтерес. Застосована в дослідженні методика на основі соиіологічних методів дозволила всебічно проаналізувати феномен злочинності неповнолітніх у статиці й динаміці та скласти «Карту комплексного вивчення особистості неповнолітнього злочиния і соиіальної ситуачії ї̈ розвитку». Результат роботи відкриває перспективу виявлення нових ознак злочинності неповнолітніх, які можуть дати початок новим напрямам наукових досліджень. 
Ключові слова: методика дослідження, неповнолітній, неповнолітній правопорушник, опитування, спостереження, аналіз документів.

Водник Валентина Давидовна, кандидат философских наук, доцент, доцент кафедры социологии и политологии, Национальный юридический университет имени Ярослава Мудрого, г. Харьков, Украина

Климова Галина Павловна, доктор философских наук, профессор, профессор кафедры социологии и политологии, Национальный юридический университет имени Ярослава Мудрого, г. Харьков, Украина

Подкуркова Ирина Валерьевна, кандидат социологических наук, доцент, доцент кафедры социологии и политологии, Национальный юридический университет имени Ярослава Мудрого, г. Харьков, Украина

\section{СОЦИОЛОГИЧЕСКИЕ МЕТОДЫ ИССЛЕДОВАНИЯ ПРЕСТУПНОСТИ НЕСОВЕРШЕННОЛЕТНИХ}

В статье раскрываются некоторые общие вопросы методики организации и проведения соииологического исследования проблемы преступности, связанной с личностью несовершеннолетних. Особое внимание уделяется методике исследования. На конкретном примере анализируются варианты дизайна выборки и возможности методов опроса, анализа документов, наблюдения, автобиографического метода и их применение к определенной исследовательской задаче. Предлагается макет итогового документа по результатам исследования - спещиальная «Карта комплексного изучения личности несовершеннолетнего преступника».

Ключевые слова: методика исследования, несовершеннолетний, несовершеннолетний правонарушитель, опрос, наблюдение, анализ документов.

\section{$\operatorname{son}$}

